\title{
A GÊNESE DA EUGENIA E ALGUMAS REFLEXÕES CONTEMPORÂNEAS
}

\author{
THE GENESIS OF EUGENICS AND SOME \\ CONTEMPORARY REFLECTIONS
}

\section{Maria Eneida de Almeida ${ }^{1}$}

\begin{abstract}
RESUMO: Este artigo destina-se a compreender as condições sócio-políticas da emergência da eugenia na sociedade do século XIX, que teve um papel relevante na estruturação do Estado moderno capitalista. A eugenia passou a ser uma ideologia científica, dando forma a políticas públicas voltadas para o melhoramento das sociedades. Por meio de análise historiográfica, observou-se que as relações de saber-poder entre sociedade, Estado e ciência moldaram uma visão de mundo baseada no paradigma social-darwinista. Este estudo teve a inspiração em Michel Foucault com a finalidade de encontrar o fio condutor do saber como uma peça do mecanismo das relações de poder de uma sociedade, onde suas microestruturas, quando vistas sob o aspecto histórico nos dá a possibilidade de delimitar saberes e poderes de um momento da história na construção de um novo mundo e de uma nova sociedade. Foi com esta forma de olhar que buscamos delinear a emergência da eugenia sob a ideia, a palavra, o conceito, a ideologia e, ao final, a própria legitimidade da ciência eugênica. Entender a gênese da eugenia enquanto existência do biopoder em determinada época passou a ser fundamental para se observar sua recorrência na contemporaneidade. Os avanços da biotecnologia possibilitam a longevidade, a cura, a fertilidade e, no limite, a imortalidade como alcance da perfeição ou da felicidade humana. Esses temas sempre foram utopias da humanidade. Entretanto, hoje são reais possibilidades e como contribuição a esta reflexão, buscamos em alguns pensadores contemporâneos os desafios inerentes à revolução biotecnológica, que foi desencadeada a partir da segunda metade do século XX.
\end{abstract}

PALAVRAS-CHAVE: Desenvolvimento biotecnológico. Eugenia. Nova eugenia.

ABSTRACT: This article is meant to understand the socio-political conditions of the engenics emergence in the society of XIX century, that have a relevant role in structuring the modern capitalist State. The engenics turned into a scientific ideology, shaping the new public policies aimed towards the societies improvement. Through historiographic analysis, it was observed that the relations of knowledge-power among society, State and science shaped a world-view based on the social-Darwinian paradigm. This study was inspired by Michel Foucault with the purpose of finding the guiding thread of knowledge as a part of the mechanism of the power relations of a society, where its microstructures, when observed under the historical aspect gives us the possibility to delimit knowledges and powers of a moment of history in the construction of a new world and a new society. That is how we tried to delineate the emergence of engenics under the idea, the word, the concept, the ideology and, in the end, the very legitimacy of engenic science. Understanding the genesis of eugenics as the existence of biopower in a certain time became fundamental to observe its recurrence in the contemporary time. Advances in biotechnology enable longevity, healing, fertility and, in the limit, immortality as the attainment of human perfection or happiness. These themes have always been utopias for humanity. However, nowadays the possibilities are real and as a contribution to this

${ }^{1}$ Professora de Saúde Coletiva do Curso de Medicina Universidade Federal Fronteira Sul - Campus Chapecó Orcid: http://orcid.org/0000-0002-0447-8760 
reflection, we seek in some contemporary thinkers the challenges inherent to the biotechnological revolution, which was triggered from the second half of the XX century.

KEY WORDS: Biotechnological development. Eugenics. New engenics.

\section{INTRODUÇÃO}

O que é eugenia? Quais as origens da eugenia? Como ela foi legitimada pela sociedade do século XIX? Como ela se tornou uma ciência em 1900? Quais são suas características? Há alguma possibilidade de recorrência eugênica com apropriação política de Estado, da ciência e da sociedade? A compreensão da gênese da eugenia pode ser útil para compreendermos a possibilidade de sua recorrência nos dias atuais, identificando a forma de sua manifestação.

Esses questionamentos buscam contribuir no esclarecimento do tema, com uma proposta que parte do fato da eugenia ter um passado complexo e estigmatizado, sendo muitas vezes evitado (e mesmo silenciado). A retorno do tema eugenia nas últimas décadas do século XX como palavra, conceito e preocupação transformou-se no fundamento deste estudo frente a inquietações despontadas no cerne das reflexões de pensadores que analisam os limites do poder da ciência, com possibilidade do surgimento de uma nova espécie humana ou nãohumana, mas biotecnológica em essência, ou ainda, a emergência de uma nova eugenia. Como reflete Laymert Garcia dos Santos (2000), a questão da preservação da espécie humana, ou de seu desaparecimento, é um problema do nosso tempo, não mais uma especulação.

\section{O CAMINHO DA PESQUISA}

Com os historiadores aprendemos que, para se pensar o novo é necessário olhar para a espiral da história e seus processos de criação e desenvolvimento, e sobretudo o que surge de novo, mas mantém permanências e surgem as recorrências. Desta forma buscamos, neste estudo, empreender uma análise sócio-histórica da gênese da eugenia de base historiográfica proveniente de pensadores que nos trazem as luzes da sociedade, da ciência e da política do século XIX como Hobsbawm (1996), Ridley (2001) e Rose (2000).

Também trazemos Foucault em suas pesquisas "Em Defesa da Sociedade" (1999) [19751976] e "Microfísica do Poder" (2016) [1979], para esse estudo quando aprendemos que o biopoder, conceito relativo à tecnologia das ciências da vida ou biociências, é um elementochave para a compreensão do poder sobre os corpos individual e coletivo, com controle do saber e com intervenção do poder, sendo o saber-poder um dispositivo que atua como agente transformador da vida humana.

Foucault se torna essencial neste texto quando aborda que a humanidade tomou conhecimento da teoria da degenerescência fundamentada no princípio da hereditariedade, e que esta reforçava a eliminação da transmissão de linhagens que apresentavam problemas físicos, mentais e estéticos. Assim as práticas eugênicas influenciaram crescentemente a literatura, a política, a antropologia, a ciência e, sobretudo o apoio legítimo da sociedade no século XIX. Segundo ele,

É a teoria da degenerescência, a sexualidade, na medida em que está no foco de doenças individuais e, uma vez que está, por outro lado, no núcleo da degenerescência, representa exatamente este ponto de articulação do disciplinar e do regulamentador, do corpo e da população. (Foucault, 1999, p. 301) 
É na prática social que se constitui no âmago do tecido social que repercute através dos mecanismos de seus efeitos e da mecânica do poder, a qual se expande por toda a sociedade (instituições, disciplinas), apontando o corpo como instrumento de técnicas de dominação. Assim Foucault tece uma análise ascendente dos micropoderes para o aparelho de Estado ao analisar o nível molecular do exercício do poder e suas produções de saberes como uma teia de relações das sociedades modernas e seus efeitos de difusão. (Foucault, 2016)

Roberto Machado, prefaciando o livro de Foucault nos diz que o poder, analisado por Foucault como qualificação das relações, é visto como uma teia de dispositivos ou mecanismos de que nada ou ninguém escapa. O poder não está situado em nenhum lugar específico na estrutura social, mas funciona como um mecanismo, ele é a própria maquinaria desse mecanismo.

A grande importância estratégica que as relações de poder disciplinares desempenham nas sociedades modernas desde o século XIX vem justamente do fato de elas nãos erem negativas, mas positivas, quando tiramos desses termos qualquer juízo de valor moral e pensamos unicamente na tecnologia política empregada. E então surge uma das teses fundamentais da genealogia: o poder é produtor de individualidade. O indivíduo é uma produção do poder e do saber”. (Machado, 2016, p.24)

Machado analisa que o sentido histórico da análise genealógica tem a acuidade de um olhar que distingue, discrimina e delimita os fatos, mas não se apóia em nenhuma base sólida, sendo que o fundamental da análise é que "saber e poder se implicam mutuamente: não há relação de poder sem constituição de um novo campo do saber, e, reciprocamente, todo saber constitui novas relações de poder". (idem-ibidem, p. 28)

O que é eugenia, sua gênese e sua legitimação são aspectos a serem desenvolvidos ao longo deste texto na trajetória da ciência, que traz a utopia da possibilidade de perfeição da espécie humana, logo, da perfeição de sociedade. Foi para alcançar respostas a tais complexidades que buscamos inspiração no método genealógico de Foucault, visto que suas investigações contribuem com o entendimento do porquê dos saberes, na explicação de sua existência, na detecção de suas transformações, situando-os como uma peça das relações de saber-poder enquanto objeto teórico, mas também como prática social instituída historicamente.

As relações tempestuosas entre o evolucionismo e os socialistas, os efeitos bastante ambíguos do evolucionismo como sobre a sociologia, a criminologia, a psiquiatria, o eugenismo, assinalam o momento importante em que, em nome de uma verdade científica "local" - por mais importante que seja - se faz a intervenção do cientista nas lutas políticas que lhe são contemporâneas. (Foucault, 2016, p. 49)

O apoio dessa acuidade foucaultiana nos possibilitou aprofundar estudos de Almeida (2002) para olhar, distinguir, discriminar e delimitar fatos trazidos da historiografia com uma abordagem do contexto sócio-político do século XIX. Delineando a emergência da ideia, da palavra, do conceito e da ideologia que deram corpo à ciência eugênica, é possível detectar a recorrência da eugenia na ciência que emergiu na segunda metade do século XX. A finalidade última é de poder trazer reflexões contemporâneas e com elas avaliar o desafio que a biotecnologia humana impõe sobre a humanidade do século XXI. 


\section{A IDEIA}

A ideia da eugenia veio das técnicas procedentes da agricultura e da pecuária nos séculos precedentes ao século XIX, em busca de um aperfeiçoamento exclusivamente técnico. $\mathrm{Na}$ agricultura, este aperfeiçoamento se deu com a seleção das melhores cepas das plantações de milho e maçãs, desde o século XVII. Na pecuária, a partir do século XVIII, com cruzamentos que geravam melhores estirpes. Essa ideia foi sendo crescentemente utilizada na agropecuária. Havia uma preocupação com a qualidade da alimentação com o aumento populacional urbano da sociedade ocidental, diante da revolução industrial. Ou seja, existia uma idéia bem-sucedida para a melhoria da agricultura e da pecuária que fundamentava uma técnica e tornou-se uma prática largamente utilizada e valorizada. (Hobsbawm, 1996; Ridley, 2001; Rose, 2000)

As pesquisas no campo da hereditariedade no século XVIII, sobre os traços morfológicos normais e anomalias, invocaram estudos sobre os fenômenos da hibridação humana e do mecanismo dos traços morfológicos. Afirma Canguilhem (1977, p 38):

A ideologia da transmissão hereditária do século XVIII era ávida de observações, de relatos que versassem a produção de híbridos animais ou vegetais, a aparição de monstruosidade. Esta ávida curiosidade tem diversos fins: decidir entre a pré-formação e a epigênese, entre o ovismo e o animalculismo; e, desse modo, encontrar soluções para problemas jurídicos de subordinação dos sexos, de paternidade, de pureza das linhagens, da legitimidade da aristocracia.

Existia uma intenção científica voltada para um processo civilizador que se esboçou antes do século XIX, fundamentada pelo campo da hereditariedade, quando se tem a origem da ideologia social do aperfeiçoamento da espécie humana voltada, neste momento, para a pureza das linhagens e legitimidade da aristocracia. Isto evidencia a força das relações de poder. Assim, para se manter o poder da realeza, a ideologia eugênica foi sendo forjada.

\section{A PALAVRA}

A hereditariedade, enquanto ideologia de uma sociedade sã teve, no estudo dos princípios da embriologia de Von Baer em 1838, uma explicação que a evolução do embrião se dá por sucessivas diferenciações celulares. Essa teoria era um passo a mais nos estudos do século anterior e acrescentava legitimidade à teoria da evolução. Canguilhem (1977) afirma que o evolucionismo foi uma ideologia científica que funcionou como uma auto-justificação dos interesses de um tipo de sociedade em conflito - por um lado a sociedade tradicional e por outro lado a reivindicação de uma sociedade 'melhorada'.

Esta reivindicação se estendeu por todos os campos do viver e do saber e a eugenia foi sendo incorporada crescentemente dentro do movimento social, por simples aceitação da sociedade. Darwin, ao estudar a biologia vegetal e animal nas ciências da vida, propôs a tese da seleção natural em sua obra principal, publicada em 1959 e proporcionou à ciência da biologia as bases da evolução humana. Entretanto, os pensadores da época interpretaram suas idéias de diferentes modos, tanto no sentido biológico individual quanto no sentido social ou sociológico.

Com a publicação de $A$ Origem das Espécies, a classe burguesa pôde racionalizar seu comportamento econômico, apelando para as leis universais da natureza como sua autoridade suprema.

PRACS: Revista Eletrônica de Humanidades do Curso de Ciências Sociais da UNIFAP https://periodicos.unifap.br/index.php/pracs ISSN 1984-4352 Macapá, v. 12, n. 1, p. 183-198, jan./jun. 2019 
Era possível, até mesmo aceitável, justificar a exploração brutal do pobre trabalhador e das aventuras imperialistas no exterior, em nome de uma leal obediência às leis da natureza. Como instrumento político o Darwinismo exaltou a competição, o poder e a violência sobre a convenção, a ética e a religião. Assim, ele tornou-se uma bandeira do nacionalismo, imperialismo, militarismo e da ditadura do culto ao herói, ao super-homem e à raça superior. (Rifkin, 1999, p.217)

Herbert Spencer, filósofo influente deste período, cunhou o termo social-darwinismo, reforçando o conceito liberal de laissez-faire ou de competição. A teoria darwinista baseada na seleção natural, sob a ótica humana social, impulsionou a eugenia como uma ideologia social.

Em 1883 Francis Galton, cientista inglês, cunhou o termo eugenia e talhou a definição desta palavra no sentido de aperfeiçoar ou de aprimorar a espécie humana através da união de pessoas que apresentassem desejadas qualidades físicas, mentais e intelectuais. Era utilizado o mesmo princípio da agropecuária. O discurso propulsor era o aperfeiçoamento da espécie humana. Foi através desta lógica que foram propostos os casamentos eugênicos, cujos cruzamentos humanos se dariam entre as 'boas estirpes' físicas, intelectuais e sociais.

Eugenia tem raiz etimológica grega - engéneia, que significa 'gerar o melhor'. Eu = bom, melhor e Genia = gerar, geração. Galton defendia a tese de que a hereditariedade dos talentos e capacidades naturais eram provenientes dos cruzamentos entre famílias de alta reputação ou posição social, as quais estariam mais propensas a terem descendentes eminentes sob algum aspecto, através da hereditariedade. Segundo Kevles, Karl Pearson, seguidor de Galton, propunha que

A Grã-Bretanha lidasse com o impacto em desvantagem das reformas liberais sobre a adequação nacional assegurando que o seguro nacional, pensões para crianças e outras melhorias, favorecessem os eugenicamente desejáveis. Pearson, entusiasta do estudo, dizia que ele não tinha nem a responsabilidade nem o conhecimento suficiente para avançar programas de lei. Ele declarou que seu principal propósito era explorar cientificamente as teorias sobre as quais uma política eugênica sadia deveria ser construída. Para reconhecer por que as nações se erguiam e caíam, tudo o que contribuía para o caráter do homem deveria ser estudado 'não por argumento verbal, mas.... com o microscópio estatístico’. (Kevles, 1995, p.34)

Dessa forma, a ideia e a palavra foram gradualmente sendo transformadas em fundamento de uma prática política direcionada, pois Pearson sustentava a hipótese de esta técnica ser um projeto incorporado na política sob regulação estatal, com fins de fortalecimento da nação e purificação da sociedade. Antes da descoberta das teorias das leis de hereditariedade de Gregor Mendel não se sabia, com exatidão, quais práticas de cruzamento humano poderiam aprimorar a linhagem humana.

O desenvolvimento da teoria de Mendel foi simultâneo à de Darwin, só que ele não teve acesso aos movimentos científicos da época e não teve a oportunidade de discutir sua teoria em ambiente científico. Por sua vez, Darwin morreu sem tomar conhecimento da teoria mendeliana, apesar desta ter sido encontrada em seus pertences. Mendel comprovou, em sua teoria, as questões que Darwin não havia conseguido desvendar. Em 1900 a teoria de Mendel foi descoberta e assim nasceu a ciência da genética, cujo termo gene foi cunhado cinco anos após, pelo cientista considerado pai da genética, William Bateson. A genética foi assim denominada pelo estudo dos genes, das unidades da hereditariedade que geram a vida ou partículas elementares construtoras do sistema físico dos seres vivos. Ao longo do século XX a genética foi 
focada em pesquisas de populações e na determinação de etnias e delimitação das raças.

Verificamos que no século XIX tivemos um encadeamento de conhecimentos da ciência da biologia evolucionista: os estudos sobre hereditariedade, a biologia darwinista e os estudos sobre reprodução. Nesta linha é que o desenvolvimento técnico eugênico em seres humanos teve sua força, fundamentado na incorporação política dos casamentos eugênicos para o progresso da nação, bem como fortalecimento e pureza da sociedade ocidental.

\section{O CONCEITO}

A partir de Galton e Spencer pode-se começar a definir a eugenia como um sentido, uma direção, e com controle do Estado. Começou a ser moldada uma sociogênese relacionada ao conceito de eugenia, atribuindo-lhe significado e força. No seio da sociedade começava a emergir a ideologia eugênica, pois o aperfeiçoamento da espécie humana era um dispositivo importante na época, voltado para o progresso nacional e modernidade da sociedade com promoção de um ideal considerado real e possível de ser conquistado através das técnicas biológicas, individuais e sociais, eliminando-se a degenerescência. Assim foi sendo consolidado o conceito de eugenia.

No período da belle époque (1870-1900), a sociedade se transformava. Havia a ascensão da biologia como ciência promissora para a constituição de uma nova sociedade, bem como as descobertas na linha da bacteriologia, com Pasteur e Koch estavam trazendo a possibilidade de cura às doenças endêmicas e epidêmicas. O movimento sanitarista crescentemente impunha a higiene da sociedade e das cidades para prevenção das doenças, sendo que neste século existia muito entusiasmo estatístico, sobretudo voltado ao tratamento dos problemas de saúde pública, com sucessos.

Galton e Pearson eram grandes estatísticos. Importante ressaltar que havia um impulso didático muito forte de aconselhamento das populações, em um esforço para esclarecer as matérias de saúde e higiene.

Esse movimento de educação em saúde tinha amplitude internacional e embora se adaptasse a circunstâncias locais, suas características eram similares em todos os países - o apelo à razão e a crença no progresso e na capacidade de aperfeiçoamento do homem. (Rosen, 1994: 139)

Havia uma importância crescente da higiene dos corpos, das populações e das cidades para o progresso e riqueza das nações, como o apogeu da hegemonia inglesa com princípios vitorianos da ordem e da moral com bons hábitos e bons costumes. Os fundamentos da teoria da evolução perpassavam todas as disciplinas científicas e legitimavam as pesquisas com reforço intelectual eugênico através das interpretações que emergiam de pensadores da época, sobretudo após a publicação da obra de Darwin na década de 1960.

A emergência do social-darwinismo influenciava a xenofobia, o racismo e o antissemitismo crescentes na sociedade euro-americana da segunda metade do século XIX. O ódio pelos estrangeiros crescia em período de formação dos Estados nacionais na Europa e no período áureo das migrações inter e intra-continentais - coloniais, econômicas e políticas.

As teorias científicas racistas sustentavam o racismo, sobretudo entre brancos/arianos e brancos/não-arianos, pois aqueles tinham sangue de 'boa linhagem', eram considerados inteligentes e faziam parte da gênese de uma raça pura. Esse era o objetivo da prática dos 
casamentos eugênicos. Existia crescentemente uma intolerância entre ricos e pobres, preconceito entre bonitos e feios e discriminação entre saudáveis e doentes.

$\mathrm{O}$ anti-semitismo, movimento contra os judeus, sobretudo comerciantes judeus, também crescia. Com estas características, o Reino Unido, cuja hegemonia política e econômica mundial refletia o império inglês da era vitoriana, se debruçava sobre o mundo, proporcionando o crescimento do liberalismo civilizatório, colonialista e, sobretudo eugênico.

\section{A IDEOLOGIA}

Como afirma Canguilhem, antes de uma ciência nascer sempre há uma ideologia que a sustenta: "A ideologia científica é movida por uma necessidade inconsciente de acesso direto à totalidade, é uma crença olhada de soslaio, do lado de uma ciência já instituída, cujo prestígio reconhece e cujo estilo procura imitar." (Canguilhem, 1977, p 41)

Nos últimos trinta anos do século XIX, tanto na sociedade quanto na política e na ciência o conceito de eugenia permeava a todos e a tudo, inclusive às instituições relacionadas à higiene individual, social e pública. Em toda sua complexidade, este conceito é um dos fios condutores que perpassam os aspectos políticos, sociais e científicos da sociedade ocidental, transformando-se em ideologia voltada à melhoria da espécie humana na busca do aperfeiçoamento social e racial. O século XIX viveu um contexto peculiar que contribuiu no desenvolvimento da ideologia eugênica e sua transformação em ciência, pelo progresso da sociedade e da ciência.

Existia um solo fértil de formulações de novas ideias e novos conceitos da sociedade que caracterizaram esta época. Foi também, neste período, que houve um acelerado processo de concentração de poder e de centralização da riqueza num reduzido número de Estados nacionais industrializados e em vias de participar do 'núcleo orgânico' de consolidação capitalista. (Fiori, 1999)

Existia um processo civilizador nas sociedades voltado ao progresso das nações e à ordem social, quando a eugenia foi um dos eixos para a delimitação e estratificação das classes sociais. Existia, neste período, uma grande mobilidade inter-classes. $\mathrm{Na}$ peculiaridade deste século, uma nova ordem estava pautada nesses temas com movimento expansivo rumo a um novo padrão social, transformando os modos de sentir, pensar e viver da sociedade da época, direcionada ao modelo de um novo homem para um mundo melhor em todos os sentidos. Buscava-se resolver os problemas graves e crônicos como as enfermidades, os conflitos sociais caracterizados pela xenofobia, racismo e anti-semitismo -, bem como a pobreza, miséria e degenerescência das margens da sociedade, reforçando a importância da civilidade vitoriana baseada na ordem, na higiene e na moral.

Ao mesmo tempo em que as epidemias assolavam as nações industrializadas, o que exigiu o nascimento da saúde pública, que pensaria na coletividade e na higiene dos lugares, dos ares e das cidades. Essa ciência voltada para a solução de problemas sociais foi em busca de respostas para um controle efetivo das doenças infecciosas que pudessem afetar o comércio internacional, que criavam riscos de contágio aos trabalhadores e, desta forma, a produtividade das fábricas e indústrias ficaria comprometida, os lucros seriam reduzidos e isso não era bom para as classes capitalistas.

Com toda sua importância desse processo civilizador, a ideologia eugênica se transformou em uma ideologia científica. Isso proporcionou e impulsionou a formulação de políticas eugênicas. Um aspecto central na construção de uma nova ciência, a ciência eugênica, foi o reforço 
do processo de biologização da sociedade sob controle do Estado.

Os eugenistas vitorianos tomaram seus preconceitos sobre raça e a "criação", naquele sentido muito inglês, projetaram-nos no darwinismo e passaram a contemplar a perspectiva de uma eugenia que cultuasse a eles e a seus valores por muito tempo, no futuro evolucionário. (Hobsbawm, 1996, p.160)

A teoria dos casamentos eugênicos, entre iguais de corpo e de mentalidade, mas, sobretudo que tivessem o mesmo padrão socioeconômico, era considerada eugenia positiva, pautada na reprodução higiênica da sociedade, elevando o padrão da nação. A eugenia negativa era a segregação e eliminação dos incapazes, dos miseráveis e dos defeituosos, além dos negros e estrangeiros. A invenção do social segundo Castel (1998) foi enfrentar, não só sistemas de privilégios, mas também fatores de desordem com riscos de desintegração da sociedade como a degenerescência.

O elo entre a ideologia eugênica e a teoria social-darwinista constituiu o paradigma darwinista, que serviu de fundamento para a legitimação da ideologia científica da ciência eugênica. Foi uma fusão das ciências sociais com as ciências naturais. A civilidade, a ordem e os bons costumes vitorianos, foram elementos essenciais da gênese dessa ideologia, faziam parte da ordem imperial inglesa e, portanto, de sua política que alcançava todo o mundo ocidental.

\section{A GÊNESE DA EUGENIA NO SÉCULO XIX}

Na década de 1890, em plena belle époque, o mundo já estava sob domínio imperial inglês, com suas políticas intervencionistas, civilizatórias, excludentes e eugênicas. Pudemos observar que a eugenia teve sua gênese a partir de três condições específicas no mundo ocidental, sobretudo nos países industrializados da Europa e nos Estados Unidos: as condições políticosociais fundamentadas na teoria do darwinismo social de Herbert Spencer; a reversão do liberalismo político que se transformou em intervencionismo civilizatório excludente; e a consolidação do paradigma darwinista como evolução biológica da espécie.

Tais condições expressaram alguns movimentos políticos como a ascensão da democracia, o imperialismo inglês sobre o mundo moldando a cultura ocidental, a intensa migração intercontinental, o otimismo da sociedade com o progresso, o triunfo das ciências naturais sob o domínio da biologia e as perspectivas favoráveis da saúde pública frente as epidemias, com a ciência da microbiologia, mais especificamente da bacteriologia e a ascensão da higiene como prática de saúde pública voltada à sociedade ocidental.

Com o movimento de consolidação do sistema capitalista no mundo ocidental desde o século XVI e seu reforço sob a hegemonia inglesa no século XIX, legitimada desde meados do século XVIII com a Revolução Industrial, o último quarto do século em estudo nesse texto, foi a afirmação do poder capitalista e científico, tanto no que diz respeito a ações voltadas à economia liberal quanto a ações e intervenções de políticas excludentes, vis a vis o poder imperial vitoriano como movimento totalitário intervencionista, na ocasião da definição dos Estados nacionais. Este foi um período da história do mundo em que a sociedade viveu uma transição a respeito dos valores nacionais, sociais e morais. Todos os aspectos da vida estavam se transformando, ao mesmo tempo em que existia uma biologização da sociedade, amalgamando o projeto eugênico.

A ideologia eugênica significou, neste sentido, marcante suporte para o racismo, xenofobia 
e antissemitismo no cerne da sociedade civil euro-americana, fornecendo as bases ideológicosociais para a legitimação da eugenia, dando impulso fundamental para sua legitimação sob bases científicas.

Levando-se em consideração a transitoriedade deste momento da história podemos apontar três aspectos. i. A sociedade civil euro-americana vivia um crescente otimismo decorrente do ideal de um novo mundo, moderno, que se concretizava em todos os aspectos da vida, ao mesmo tempo em que vivia um pessimismo que se fazia sentir pelas políticas econômicas repressivas. ii. A sociedade política preocupava-se com a formação da identidade nacional dentro do movimento de conformação e delimitação do Estado moderno, que focava a ordem e o progresso sob a higiene das cidades e de suas populações. iii. A sociedade científica consolidava o paradigma darwinista, fornecendo a legitimação da ideologia eugênica como ideia de aperfeiçoamento biológico da espécie humana e da sociedade, em íntima conexão com a ideia de construção de uma raça pura, perfeita, ariana, que, crescentemente, se tornava possível através da crença na ciência que se afirmava como uma verdadeira fé.

No período conhecido como belle époque, a sociedade ocidental vinha de um fenômeno biossociológico crescente, dentro de uma bio-regulamentação do Estado. E neste sentido a pureza da raça e a higiene das cidades e das pessoas eram fatores de progresso da nação, na busca de uma felicidade e da saúde individual, social e coletiva, portanto, livre de toda e qualquer doença, incluindo qualquer defeito físico ou incapacidade mental. Assim, as pessoas que não eram vinculadas a linhagens positivas com proposições ideológicas raciais, eram excluídas, segregadas e eliminadas.

Desde a segunda metade do século XIX, os Estados Unidos começaram a reconhecer o movimento eugênico europeu. A vanguarda científica, originalmente de exclusividade europeia, começava a ser apropriada também pelos americanos. Os movimentos científicos, sociais e políticos do movimento eugênico britânico original, foram sendo reconhecidos e o crescente interesse americano deu, aos Estados Unidos, o papel de principal protagonista e formulador oficial da ciência eugênica - de seu nascimento e de sua legitimação -, ultrapassando todos os ideais políticos eugênicos britânicos. Galton e Pearson, os pais da eugenia do império vitoriano admitiram, nos primeiros anos do século XX, as limitações científicas de suas teorias que focavam uma política eugênica nacional frente à proposição dos casamentos eugênicos e de formulação de políticas públicas pautadas num modelo biológico.

O método eugênico europeu forneceu as bases aos cientistas americanos e tomou forma mais bem definida, sendo formulada cientificamente a partir de 1900, quando sua sistematização fundamentou a formulação de políticas públicas adequadas ao ideal de uma nação moderna. Isso deu grande impulso para a elaboração de um grande projeto nacional de controle sistemático do Estado, na direção dos indivíduos e da população através da seleção, segregação, exclusão e eliminação dos 'indesejáveis' ou 'inaptos’ da nação.

Como diz Black (2003), foi uma 'cruzada eugênica' mundial, mas de modelo americano. Esta cruzada atingiu ‘todos’ os Estados nacionais que possuíam suas ciências nacionais, ou seja, Estados industrializados, sobretudo os do pequeno núcleo das Grandes Potências que controlavam o poder político e financeiro mundial, Inglaterra, Estados Unidos, França, Alemanha. Desta forma, todas as nações foram sendo permeadas pela nova ciência, configurando um grande movimento político intervencionista internacional científico eugênico.

A eugenia, em 1900, já estava incorporada no inconsciente coletivo da sociedade ocidental. Em poucos anos começaria a ser aplicada na educação de maneira geral e na prática médica, 
com legitimidade mundial. A eugenia passou a fazer parte do senso comum, para a estruturação de uma nação constituída de indivíduos higiênicos e puros, arianos em essência, o que era considerado o ideal da sociedade moderna.

Black (2003) salienta que assim que a eugenia entrou nos Estados Unidos, pretendeu-se global. Foi a partir de uma sistematização metodológica programática e peculiar americana que, ao longo de toda a primeira metade do século XX, conduziu e dominou a ciência eugênica através de suas técnicas e modelos especificamente desenvolvidos. Em suma, o movimento eugênico da Inglaterra foi a gênese da ciência eugênica, mas o seu nascimento deu-se já nos Estados Unidos. Em ambos países era um projeto de poder de dominação global, com a descoberta de uma forma de conduzir cientificamente o cruzamento dos seres humanos.

\section{REFLEXÕES CONTEMPORÂNEAS}

Para Rifkin (1999), Sfez (1995), Wilkie (1994), Kevles (1995), Black (2003) e outros pensadores contemporâneos, a humanidade vive um momento decisivo na sua trajetória. Já no final da década de 1960 uma mudança estava prestes a ocorrer.

A íntima relação entre micróbios e homens reside na descoberta de uma bateria de enzimas, produzidas por bactérias e vírus, que podem ser usadas na manipulação do DNA. Gradualmente, quase sem o perceber, os pesquisadores começaram a reunir um poderoso material instrumental que lhes permitia 'editar' o texto genético escrito na hélice dupla. Descobriram tesouras moleculares com que podiam cortar fragmentos de texto e uma fita adesiva biológica para colar os pedaços do texto editado. Mais importante que tudo, começou-se a perceber que o conjunto microbiano de ferramentas para a edição do DNA era capaz de localizar textos específicos dentro do DNA. A descoberta dessas ferramentas de edição e do modo como podiam ser utilizadas tornou possível o sonho de mapear e seqüenciar o genoma humano. (Wilkie, 1994: 71).

Logo nos três primeiros anos da década de 1970 aconteceu um ponto de mutação em toda a linhagem da ciência da biologia e suas aplicações (medicina, farmácia, pecuária, agricultura, etc). Não foi um salto somente qualitativo no campo da ciência, mas um salto que causou uma profunda ruptura e começou a alterar a estrutura conceitual, empírica e teórica das ciências biológicas em geral. Foram descobertas as 'tesouras' químicas (enzimas) que cortariam a dupla hélice de DNA em lugares específicos com grande precisão, fragmentando-o como o desejado e também descobriram como que uma 'fita durex' bioquímica (enzimas) com a propriedade de colar os fragmentos extraídos da dupla hélice.

Seria possível, finalmente, fazer um tipo de dissecação do DNA, reconstruindo-o conforme desejado ou programado. Essa biotécnica chama-se DNA recombinante e foi o ponto de mutação radical no desenvolvimento biotecnológico porque foi o passo que tornou possível todo e qualquer desenvolvimento científico das ciências da vida e de suas aplicações, como a viabilidade de fabricação de quimeras, os organismos geneticamente modificados. Esta é a grande revolução biotecnológica do século XX.

A invenção da biotécnica de DNA recombinante criou um instrumento de ação para os outros avanços que se sucederam como, por exemplo, o bebê de proveta, a ovelha Dolly, as células-tronco para clonagem reprodutiva e terapêutica, a abertura da ciência da nanotecnologia, entre outros.

PRACS: Revista Eletrônica de Humanidades do Curso de Ciências Sociais da UNIFAP 
O instrumento relacionado a tais desenvolvimentos foi a engenharia genética ou bioengenharia; campo específico para a prática da combinação e recombinação de genes. Combinação de genes significa a fusão de genes de animais com vegetais de espécies diferentes entre si, de vegetais com animais, de vegetais com humanos, de animais com humanos ou ainda de humanos com humanos. O produto dessa mixagem biotécnica dá-se o nome de quimera.

Existem 'n' experimentos de sucesso desde a invenção desta técnica que, nos dias atuais são bem conhecidos e comuns. Alguns exemplos originais são: cenoura que brilha no escuro é produto da combinação de genes do vagalume e da cenoura; Insulina sintética é produto da colagem do gene humano (no gene de) numa bactéria; combinação de genes de tomates em peixes linguado, produz tomates protegidos contra os danos da geada pois os linguados têm uma proteína anticongelamento; genes de galinha em batatas para aumentar resistência às pragas; genes de hamster chinês em pés de tabaco para aumentar a proteção de esterol etc. Muitos produtos agrícolas fazem parte das lavouras geneticamente modificadas e estão no mercado, os alimentos e os produtos transgênicos ou quiméricos.

A biotécnica do DNA recombinante proporciona a possibilidade de cortar, recortar e costurar DNA de qualquer ser vivo, independente do reino ou da espécie. É isso que se chama manipulação do código genético. Neste ponto, a genética foi radicalmente revolucionada. Segundo Wilkie (1994), Paul Berg, da Universidade de Stanford-Califórnia, com mais dois cientistas construíram o primeiro DNA recombinante no período de 1970-71, a primeira quimera construída, de fato, ao se cortar e colar um pedaço de DNA de bactéria com o pedaço de DNA de um vírus. A partir desse ponto, novos desdobramentos e grandes projetos poderiam ser possíveis e novas ideias poderiam seguir alargando as margens da ciência. E as doenças poderiam ter um fim ou, no mínimo, uma perspectiva interessante de cura ou tratamento. Os desdobramentos científicos contemporâneos no campo da biotecnologia têm sua origem na biotécnica do DNA recombinante. Novas experiências foram se multiplicando e se diversificando. Os cientistas tinham, nas mãos, um novo universo a ser descoberto.

Em 1972, com a facilidade crescente de construção de quimeras, começou a haver uma certa inquietação de alguns biólogos moleculares sobre a ética e a segurança dos experimentos de DNA recombinante. A questão principal de preocupação por parte dos biólogos moleculares era o que estaria se abrindo para as ciências da vida, com os avanços biotécnicos emergentes. Seria possível a miscigenação de raças e/ou espécies, de fato? Para os seres humanos também?

Tudo apontava para o sim. E seria então, possível o desenvolvimento de pragas mutantes? Novas bactérias? Novos vírus? Novas doenças? Então, isso tudo faria parte da segurança nacional porque este novo poder poderia ser usado para a guerra. Um dos questionamentos fundamentais dos cientistas da revolução biotecnológica era em qual dimensão da ciência biológica estaria, então, a humanidade entrando.

\section{A GÊNESE DA NOVA EUGENIA NO SÉCULO XX}

Jeremy Rifkin nos diz que biotecnologias são as novas ferramentas de sonhos, pois dão o poder aos seres humanos de criar uma nova visão sobre si e sobre todo o mundo vivo. E mais, dá a nós a capacidade de atuar sobre isso tudo. Nas palavras do autor,

A antiga eugenia se calcava em uma ideologia política e era motivada pelo medo e pelo ódio. A nova [eugenia] é impulsionada pelas forças de mercado e pelos desejos do consumidor. É errado, 
perguntam os biólogos moleculares de hoje, desejar bebês mais saudáveis? A nova eugenia não chega até nós como um complô sinistro, mas como um benefício social e econômico. Ainda assim, por mais que se tente, não há como ignorar que o novo esforço comercial para reprojetar os genótipos da vida na Terra está nos conduzindo ao limiar de um novo século da eugenia. (...) É difícil imaginar os pais recusando modificações genéticas que prometem aumentar, de certa forma, as oportunidades de seus descendentes. (Rifkin, 1999, p. 135-147).

Para Rifkin, a biotecnologia é o fundamento de uma nova economia mundial e os genes são a base de uma era bioindustrial em substituição à era industrial que moveu toda a modernidade. A criação de novas formas de vida, no que toca os vegetais, animais e humanos estaria moldando o mundo bioindustrial, pois viveríamos um mundo alicerçado em uma indústria 'de vida', uma indústria biológica global que estimula, por decorrência, permanente e crescentemente, um mercado biológico global. Diz ele que os produtos seriam novas formas de vida comerciáveis e, para tanto, megaempresas estão envolvidas, as quais formam os grandes conglomerados industriais-biotecnológicos que fabricam e comercializam produtos e subprodutos cujos recursos primários, ou matéria prima, são 'genes'.

Todo o processo do lucro biotecnológico atual são produtos e subprodutos das invenções e inovações científicas da década de 1970. Desde então, o que surgiu, e diariamente surge, são subprodutos desse processo, que emergiram como subsídios no jogo de interesses políticoeconômico/financeiros e científicos.

Segundo outro pesquisador que questiona a revolução biotecnológica no campo da bioética, Laymert Garcia dos Santos, sobre os riscos que a preservação da espécie humana corre, reflete: "A espécie humana parece ter chegado ao seu estágio terminal enquanto o relógio da história é zerado, já que somos instados a reconstruir o mundo sobre novas bases” (Santos, 2000, p. 58). E, nesse sentido o autor trabalha o conceito de dignidade como um conceito supra-individual, visto que é remetido à espécie humana como um todo. Este conceito configura a dimensão coletiva, sendo a dignidade uma qualidade de pertencimento dos seres humanos, o que designa a 'humanidade' do Homem e não somente o 'ser' do Homem. A dignidade é a essência da humanidade e, desta forma, se esta última se situa no plano do direito natural supranacional, a primeira também deve estar neste patamar.

No paradigma da humanidade há o pressuposto de que a dignidade está fora do comércio. A vida não deve e nem pode ser comercializada, pois o indivíduo não deve dispor de sua dignidade, não pode aliená-la nem renunciar a ela, porque não pode se excluir da humanidade. Entretanto, como reflete o autor, se a vida está sendo comercializada - órgãos, pele, olhos..., isso pode indicar que aqui se apresenta um paradoxo: a integridade do ser humano enquanto membro da espécie humana está ameaçada pela conquista da natureza humana e há possibilidade real de apropriação da vida humana em sua dimensão molecular. (Santos, 2000).

A produção científica e tecnológica avançou muito mais do que o esperado. Chegou a estágios de conhecimento que não só possibilita a procriação humana sem sexualidade, mas rompeu grandes dogmas científicos, éticos e econômicos. (Carneiro \& Emerick, 2000). Hoje é de importância fundamental um processo de aprofundamento da reflexão dos avanços da biotecnologia em direção à sociedade humana do século XXI, precisariam ser guiados, orientados e muito bem compreendidos.

Os pensadores citados apontam, de uma forma ou de outra, a ruptura da espécie humana como um aspecto da biotecnologia, com a transformação genética sendo possível e viável. Mas só para as classes sociais com alto/altíssimo poder aquisitivo. E o retorno da eugenia é 
fato e não uma suposição. Uma eugenia diferente, sem indícios de determinação governamental. Ela está na esfera de uma escolha 'individual', dentro do consultório médico. Entretanto esta escolha merece profundas reflexões, como demonstrou Kevles, que o eugenismo clássico transformou-se,

(...) de um programa social de transformação ele se torna um programa familiar de conhecimentos com vistas a melhorar as decisões individuais e na mesma linha, o sociólogo Troy Duster nos revela um verdadeiro "retorno ao eugenismo" soft, adaptado às populações negras ou a certas categorias de judeus ashkenazes. (SFEZ, 1995, p.172)

Sfez revelou a emergência de um verdadeiro 'retorno ao eugenismo soft', adaptado às populações negras e ou a certas categorias de judeus, sublinhando que a genética não é responsável pelo racismo, mas se 'enrosca admiravelmente em suas espirais', pois "o pretenso poder individual esconderá o poder institucional." (Sfez, 1996, p. 173)

Sendo assim, o individualismo acaba sendo uma falácia em termos de biotecnologia humana, se observarmos que a escolha individual acaba se apresentando 'sem escolha', quando se avalia o poder financeiro envolvido nas escolhas genéticas. Isto é, as pretensas escolhas dependem fundamentalmente do poder aquisitivo do pretendente e das instituições que as possibilitam.

Kurz fala que se acreditava que a pesquisa genética contemporânea desbancaria os despropósitos racistas:

Mas tais constatações curvam-se, hoje, cada vez mais sob o peso de uma nova 'biologização' da conduta social. Tais estudiosos são muitas vezes ingênuos sob a ótica social e, assim, talvez, não percebam que suas pesquisas, puramente objetivas, sofrem a influência de correntes ideológicas que solapam a sociedade. (Kurz, 1997, p. 195)

Black afirma que essa era genética, que se transforma e transubstancia em tão alta velocidade, dificilmente pode ser compreendida pela imensa maioria da população mundial que nem sequer conhece ou fala a linguagem da engenharia genética, insulando-se sobretudo num amplo espectro de revistas e de simpósios científicos que, ao final, são esclarecedores somente aos cientistas especializados. "Além disso, poucos conseguem ficar a par das implicações morais, legais e tecnológicas da evolução quase inacreditável das descobertas genéticas, especialmente porque a maior parte da informação é absolutamente técnica”. (Black, 2003, p. 674)

\section{CONSIDERAÇÕES FINAIS}

Para se trazer reflexões contemporâneas e com elas avaliar o desafio que a biotecnologia humana impõe sobre a humanidade do século XXI, foi preciso retornar ao contexto sóciopolítico do século XIX na origem da eugenia como ciência legítima. E os fatos trazidos nos mostra que, na contemporaneidade os desafios do desenvolvimento da biotecnologia têm sido a expressão fundamental de todos os pensadores que se preocupam com a dignidade da espécie humana a respeito do debate sobre a emergência da nova eugenia. É nosso papel afirmar nossa humanidade e reforçar a dignidade da espécie humana acima dos avanços da ciência, em prol das próximas gerações de seres humanos 'naturais'. Este artigo entra nesta discussão. A compreensão de sua gênese é essencial para se observar com olhos cuidadosos sua recorrência

PRACS: Revista Eletrônica de Humanidades do Curso de Ciências Sociais da UNIFAP https://periodicos.unifap.br/index.php/pracs ISSN 1984-4352 Macapá, v. 12, n. 1, p. 183-198, jan./jun. 2019 
na contemporaneidade. Verificamos que foram as orientações científicas e técnicas que deram à molde às políticas eugênicas no século XIX, legitimadas pela sociedade.

Foucault (2016) diz que o saber funciona em todos os níveis da sociedade, de mãos dadas com o poder. É um mecanismo do saber-poder. E diz que é preciso refletir sobre os aspectos positivos do poder, sua força transformadora e produtiva, e transcender a visão única de que o poder é negativo e destrutivo. Enquanto há positividade, há riqueza estratégica, que é justamente esse aspecto positivo que explica o fato de ter como alvo o corpo humano para aprimorá-lo, melhorá-lo, adestrá-lo, moldá-lo e regulá-lo.

Este saber-poder emerge nas sociedades do século XIX quando aparecem os avanços científicos da biologia, da sociologia, da política, da economia, da bacteriologia, da saúde pública e da eugenia. O biopoder, enquanto tecnologia do saber e do poder tem como objeto e como objetivo, a 'vida'. E foi exatamente nesse sentido que buscamos refletir neste texto sobre a gênese da eugenia original, para ser possível olhar os mecanismos que encadearam a eugenia na vida social, política e científica.

De ideias originais à palavra de ordem; de um conceito à chave de um processo social na hegemonia de uma ideologia-força que emergiu na sociedade civil, científica e política de uma época que, em síntese, ao se transformar em ciência, fez parte da dominação política de corpos individuais e de toda sociedade ocidental, segregando, exterminando e aniquilando os povos em nome do progresso das nações, da higiene da sociedade, da ordem e do progresso científico. Ao final, foi uma época que, apesar de se dizer bela, não deixou saudade diante da perversidade que se abateu sobre a sociedade decorrente da hegemonia da ideologia eugênica no Ocidente.

A questão da tecnologia é uma questão complexa nas ciências da vida, visto que seus desdobramentos biotecnológicos podem fornecer conhecimentos tanto para instrumentalizar o poder para a guerra, como aponta Almeida (2015, p. 2256),

Ao longo do século XX e, até a atualidade, foi desenvolvido um amplo campo de pesquisa e desenvolvimento tecnológico da biologia, a biologia da guerra ou biologia militar, que trabalha na invenção e desenvolvimento de armas biológicas. (...) Na segunda metade do século XX, o avanço biotecnológico teve uma relação cada vez mais estreita com as estratégias de poder, na busca pela ponta científica, através de uma corrida bipolarizada da biologia.

Mas acompanhando a gênese da eugenia verificamos que a biotecnologia também forneceu instrumentos de controle social e populacional. E foi nesse aspecto que este estudo buscou retraçar a gênese da eugenia, questionando os desafios do desenvolvimento atual da tecnociência das ciências da vida, ou da biotecnologia, e seus desdobramentos na segunda metade do século XX até os avanços atuais relacionados aos conceitos eugênicos. Está posto um grande desafio sobre nossas cabeças, pois o poder da tecnologia sobre o corpo humano e sobre o corpo social é um dos fatos da história da humanidade que deu grande contribuição ao arrefecimento das duas grandes guerras mundiais do século XX e, assim, à quase aniquilação de um povo. (Cohen, 1998)

Stephen Hawking, cientista renomado que lutou com sua doença genética ao longo de toda sua vida, em entrevista para televisão no ano 1999, sobre os avanços da ciência, disse:

Se há algo que aprendemos com a genética é que a tecnologia nos atinge como um trem de carga, antes que estejamos preparados para ela. Ela chegará. E será sem aviso e rápida. Acho 
que algum tipo de evolução autoprojetada está destinada a acontecer. Não adianta nos lamentarmos. O melhor que podemos fazer é tentar guiá-la. De certo modo, dou boas-vindas à genética. Significa que formas de vidas biológicas têm chance de ficar na frente das eletrônicas.

Em 2001, James Watson, descobridor da dupla hélice, afirmou em matéria da Folha de São Paulo em 18 de abril, que é legítimo modificar os genes das futuras gerações. "Pioneiro do DNA defende a nova eugenia: 'sou fortemente favorável a controlar o destino genético de nossos filhos. Trabalhar inteligente e sabiamente para fazer com que bons genes dominem o maior número de vidas possível é o modo verdadeiramente moral de procedermos"”.

São imensas as dificuldades de compreensão da ciência da biologia e dos desenvolvimentos da biotecnologia humana. Há uma inexorabilidade diante da construção de um mundo biotecnológico, excludente, com um grau elevado de racionalismo e de individualismo científicos, sob a ênfase discursiva basicamente voltada para um tripé de positividade: a solução para a infertilidade, o direcionamento tecnológico das ciências da vida voltados a tratamentos antes inimagináveis, com promessas de curas no corpo físico, mental e emocional, e a busca pela longevidade humana, com pesquisas que beiram (ou espreitam) a imortalidade. A humanidade vive um processo científico cujo progresso tem o fundamento no discurso da felicidade. Porém, pouco se fala sobre a contramão desse processo ou de suas próprias contradições.

A biotecnologia contemporânea é produto de uma revolução científica possibilitada pelos avanços de um grande feixe de ciências, porém ainda não foi dado o distanciamento necessário ou a sociedade ainda não teve condições de refletir a respeito dos aspectos positivos e negativos inerentes a este processo. Algumas contradições deste mundo biotecnológico estão sendo analisadas por pensadores em vários campos da ciência: na biologia, na ética, na economia, na política, na política internacional. Um novo discurso sobre a vida e sobre a morte começou a emergir com a descoberta do DNA em início da década de 1950 e se aprofundou com os avanços científicos a partir da década de 1970.

Foi um caldo de inovações que deu origem à revolução biotecnológica cujo desenvolvimento reabriu as portas da eugenia, lembrando que a eugenia foi banida enquanto ciência em todo o mundo ocidental após a segunda grande guerra, mas as pesquisas tiveram continuidade. E, como diz Kevles (1995), há um espectro permanente da eugenia no desenvolvimento contemporâneo. Este espectro esteve adormecido sob o manto da ciência da genética humana. Nas palavras de Foucault,

Esse excesso de biopoder aparece quando a possibilidade é técnica e politicamente dada ao homem, não só de organizar a vida, mas de fazer a vida proliferar, de fabricar algo vivo, de fabricar algo monstruoso, de fabricar - no limite - vírus incontroláveis e universalmente destruidores. Extensão formidável do biopoder que vai ultrapassar toda a soberania humana. (1999, p. 303)

Consideramos importante deixar um questionamento sobre o biopoder, uma tecnologia do saber e do poder, que tem como objeto e como objetivo, a 'vida'. Estaria o biopoder enredado na nova eugenia, encadeado na vida social, política e científica?

Ao raiar do século XXI nasceu a ciência genômica, anunciada em 26 de junho de 2000, sendo a decifração do DNA humano o principal resultado do Projeto Genoma Humano. Seus desdobramentos estão se dando para toda a humanidade, com aspectos complexos que tanto contribuem com a sociedade, quanto com aspectos que são os grandes desafios do nosso 
tempo. No contexto de um mundo que se transforma sob a revolução biotecnológica em curso, este estudo nos trouxe uma certeza, de que é preciso estar atento e manter a reflexão sobre as biotecnologias, questionando-as a todo tempo a respeito de seus limites técnicos e científicos.

\section{REFERÊNCIAS}

ALMEIDA, M. E. A permanente relação entre biologia, poder e guerra: o uso dual do desenvolvimento biotecnológico Ciência \& Saúde Coletiva, Rio de Janeiro: ENSP/FIOCUZ, 20(7):2255-2266, 2015.

ALMEIDA, M. E. Ciência Eugênica: gênese e nascimento de uma nova ciência (1870-1900). Dissertação de Mestrado IMS/UERJ. Mimeo. 2002. Orientadora: Madel T. Luz. Financiamento: FAPERJ.

BLACK, E. A Guerra Contra os Fracos. São Paulo: A Girafa, 2003.

CANGUILHEM, G. Ideologia e Racionalidade nas Ciências da Vida. Lisboa: Edições 70, 1977,

CARNEIRO, F.; EMERICK, M. C. (org.). Limite: a ética e o debate jurídico sobre acesso e uso do genoma humano. Rio de Janeiro: Fiocruz, 2000.

CASTEL, R. As Metamorfoses da Questão Social. Petrópolis: Vozes, 1998.

COHEN, P. Homo Sapiens. 1900. Documentário. 1998. Acesso em 15 fevereiro 2018. Disponível em: https://www.youtube.com/watch?v=TPSjjElIIZM

FIORI, J. L. (org.) Estados e Moedas no Desenvolvimento das Nações. Petrópolis: Vozes, 1999.

FOUCAULT, M. Em Defesa da Sociedade. São Paulo: Martins Fontes, 1999 [1975-1976]. - Microfísica do Poder. Rio de Janeiro: Paz e Terra, 4ª ed, 2016 [1979].

HOBSBAWM, E. A Era dos Impérios: 1875-1914. Rio de Janeiro: Paz e Terra, 1996.

HUXLEY, A. Admirável Mundo Novo. Biblioteca Universal: Unibolso.

KEVLES, D. J. In the Name of Eugenics: genetics and the use of human hereditary. New York, Knopf, 1995.

KURZ, R. Os Últimos Combates. Petrópolis: Vozes, 1997.

MACHADO, R. Por uma Genealogia do Poder. IN: FOUCAULT, M. Microfísica do Poder. Rio de Janeiro: Graal, $4^{\mathrm{a}}$ ed, 2016 [1979].

RIDLEY, M. Genoma: a autobiografia de uma espécie em 23 capítulos. Rio de Janeiro: Record, 2001.

RIFKIN, J. O Século da Biotecnologia: a valorização dos genes e a reconstrução do mundo. São Paulo: Makron Books, 1999.

ROSE, M. O Espectro de Darwin: a teoria da evolução e suas implicações no mundo moderno. Rio de Janeiro: Jorge Zahar, 2000.

ROSEN, G. Uma História da Saúde Pública. Hucitec/Abrasco: São Paulo/Rio de Janeiro, 1994.

SANTOS, L. G. Invenção, Descoberta e Dignidade Humana. IN: CARNEIRO E EMERICK (org.) Limite. Rio de Janeiro: Fiocruz, 2000.

SFEZ, L. A Saúde Perfeita: crítica de uma nova utopia. São Paulo: Loyola, 1996.

WILKIE, T. Projeto Genoma Humano: um conhecimento perigoso. Rio de Janeiro: Jorge Zahar, 1994.

PRACS: Revista Eletrônica de Humanidades do Curso de Ciências Sociais da UNIFAP

https://periodicos.unifap.br/index.php/pracs ISSN 1984-4352 Macapá, v. 12, n. 1, p. 183-198, jan./jun. 2019 